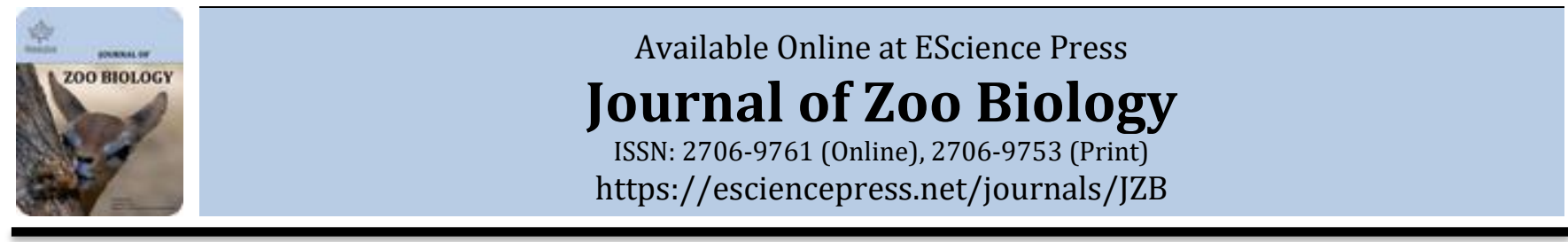

\title{
NUCLEAR DAMAGE IN PERIPHERAL ERYTHROCYTES OF CYPRINUS CARPIO EXPOSED TO BINARY MIXTURE OF PESTICIDES
}

aFaiza Ambreen*, bMuhammad Javed

a Department of zoology, Government College women University, Faisalabad-38040, Pakistan.

b Department of Zoology, Wildlife \& Fisheries, Laboratory of Aquatic Toxicology, University of Agriculture, Faisalabad38040, Pakistan.

*Corresponding Author Email: faiza_zool@yahoo.com

\section{A B S T R A C T}

The present study was undertaken to examine the DNA damage in peripheral blood erythrocytes of Cyprinus carpio under the binary exposure of bifenthrin and chlorpyrifos by using single cell gel electrophoresis (SCGE). Limited efforts have been made to study the genotoxic effect for long duration period. Therefore, the present investigation was aimed to assess the genotoxicity of pesticide mixture to the freshwater carp, Cyprinus carpio at sub-lethal concentration exposure (33\% $\mathrm{LC}_{50}$ ). At first $96-\mathrm{hr} \mathrm{LC}_{50}$ value of pesticide, the mixture was determined for Cyprinus carpio in a static system and then sub-lethal concentration was calculated and fish was exposed to this sub-lethal concentration of the mixture in glass aquaria for 70 days (five fortnights) at constant laboratory conditions. Peripheral blood erythrocytes were taken on a fortnightly basis for the time-dependent DNA damage assessment in-terms of percentage of damaged cells, genetic damage index and a cumulative tail length of comets. Concentration-dependent increase in the percentage of DNA damaged cells were observed up to a $4^{\text {th }}$ fortnight, followed by a slight decrease in the $5^{\text {th }}$ fortnight. Similarly, statistically significant time-dependent DNA damage was observed in terms of percentage of damaged cells, genetic damage index and a cumulative tail length of comets in treated fish (at $33 \%$ of $\mathrm{LC}_{50}$ ) as compared to control groups. The results supported the use of SCGE for evaluating the toxicity of pollutants which may be used as part of environmental monitoring programs.

Keywords: Pesticide mixture, Cyprinus carpio, DNA damage, single cell gel electrophoresis.

\section{INTRODUCTION}

Pesticides, in particular, have received increasing attention given their suggested important role in the global loss of freshwater biodiversity and ecosystem functioning (Malaj et al., 2014; Ramussen et al., 2015) because pesticides of various groups are used indiscriminately against a number of pests in the field to increase crop yield. Residues of these pesticides reach the aquatic environment, representing a risk for the nontarget organisms (Ruiz-Suarez et al., 2015). Genotoxicity of pesticides for non-target organisms and their impact on ecosystem are of worldwide concern.

In the last decades, organophosphate pesticides are among the most widely used classes of pesticides. China, India and other countries have substantially increased the production of organophosphate pesticides even in recent years (Yen et al., 2011). Organophosphate pesticides are often implicated as toxic and alkylating agents and potential genotoxicants. As a well-known organophosphate pesticide, chlorpyrifos is extensively used for controlling agriculture and household pests all over the world (Yen et al., 2011). In 2007, chlorpyrifos was the fourteenth most commonly used conventional active ingredient in the agricultural pesticide market sector (Grube et al., 2011). Runoff events, erosion and leaching are the major routes of chlorpyrifos entry into surface waters (Jin et al., 2015). Another pesticide class, pyrethroid is recently extensively used nowadays and some evidence indicates that these chemicals are genotoxic in some systems including fish (Ambreen and Javed, 2015). Bifenthrin is active insecticide belongs to pyrethroid group of pesticide and is used in agriculture and public health control programs (control of mosquitoes) that act as a contact stomach poison. It 
affects the central and peripheral nervous system and cause synaptic discharge, depolarization and ultimately cause death and it also acts as ATPase inhibitor in fish (Ponepal et al., 2010).

A primary risk factor of genotoxic pesticides is that they can interact directly or indirectly with chromosomal DNA, causing chronic genotoxicity such as carcinogenic and reproductive toxicity (Xiang et al., 2013). It is evident that chemical, physical and biological agents could interact with the genetic material, resulting in mutations which are associated with genomic instability and cancer (Malling, 2004). Regulatory agencies like Food and Drug Administration (FDA) and European Medicines Agency (EMA) now begun to require that different genotoxicity tests (Hartmann, 2004). These tests include in vitro and in vivo assays to detect the potential of genotoxic agents to induce genetic mutations and/or chromosomal aberrations (Araldi et al., 2015). Among different tests used for genotoxicity, SCGE is a very sensitive and rapid assay that can be applied to nucleated cells for the detection of DNA damage at a single cell level. Single cell gel electrophoresis assay allows us to detect DNA strand breaks, which can be visualized by the increased migration of free DNA segments, resulting in images similar to comets (Azqueta and Collins, 2013). The single cell gel electrophoresis or comet assay was introduced by Ostling and Johanson (1984). Since its development, several methodological modifications were proposed however, the Alkaline method, developed by Singh et al. (1988) that allows the DNA denaturation, double-strand breaks (DSBs), single strand breaks (SSBs), detection of alkali-labile sites, became the most used and recommended because of its broad spectrum for DNA damage detection. These DSBs and SSBs are associated with chromosomal aberrations and genomic instability (Pfeiffer et al., 2000).

In natural environments, contaminants usually present as complex mixtures (Ambreen and Javed, 2015) because cocktails of compounds create a huge problem as the toxicity of a mixture is not easily linked to individual toxicities of components in the mixture. The common carp was selected as the test fish because it is one of the most economically important freshwater fishes of the world and because there is a scarcity of information regarding the genotoxicity of pesticide mixture on freshwater fishes.

\section{MATERIALS AND METHODS}

The fingerlings of freshwater fish, Cyprinus carpio (180- day age) were purchased from local fish seed hatchery and transported to Fisheries Research Farms, University of Agriculture, Faisalabad, Pakistan. Healthy fingerlings of similar weight were acclimatized under laboratory conditions in cemented tanks for about ten days and fed with a nutritious diet. Bifenthrin and chlorpyrifos were dissolved, separately, in $95 \%$ analytical grade methanol (J.T Baker) as a carrier solvent to prepare the stock-I solutions $(1 \mathrm{~g} / 100 \mathrm{ml})$ while a binary mixture of these pesticides were prepared by its further dilutions in deionized water (stock-II). The acute toxicity bioassay to determine the 96-hr $\mathrm{LC}_{50}$ value of pesticide mixture (bifenthrin+chlorpyrifos) was conducted in a static system. The $96-\mathrm{hr} \mathrm{LC}_{50}$ was determined as $0.76 \mu \mathrm{gL}^{-1}$ for Cyprinus carpio by using the Probit analyses method. Based on this 96-hr $\mathrm{LC}_{50}$ value, one test concentration i.e. $33 \%$ of $\mathrm{LC}_{50}\left(0.25 \mu \mathrm{gL}^{-1}\right)$ was calculated and used for the assessment of sub-lethal genotoxicity experiment.

Single Cell Gel Electrophoresis (SCGE): The experiments were conducted in glass aquaria to determine the extent of DNA damage in the peripheral blood erythrocytes of Cyprinus carpio. For this purpose, the thirty-six fingerlings of Cyprinus carpio were divided into three groups. The first group were exposed to 33\% $\mathrm{LC}_{50}$ of pesticide mixture (test concentration), the second group of fish were maintained in tap water considered as "Negative Control" (unstressed group), while in third group cyclophosphamide (20 ggg- $^{-1}$ ) was used as "Positive Control". During the whole experimental period, fish were fed daily with a small quantity of food. Water temperature $\left(30{ }^{\circ} \mathrm{C}\right), \mathrm{pH}(7.75)$ and total hardness (225 $\mathrm{mgL}^{-1}$ ) were kept constant throughout the experimental duration. Exposure was continued for 70 days and blood erythrocytes slides were prepared on a fortnightly basis from all experimental groups and subjected to alkaline single cell gel electrophoresis (Comet assay). The experiment was conducted with three replications. Alkaline single cell gel electrophoresis was performed as three layer procedure by following the methods of Singh et al. (1988). Blood samples were collected from the caudal vein of fish transferred in Eppendorf and treated with anticoagulants and diluted with $1 \mathrm{ml}$ of phosphate buffer saline (PBS). Blood (60 $\mu$ l) was mixed with $110 \mu \mathrm{l}$ of $1.7 \%$ low melting point (LMP) agarose. Sample mixture then layered on the glass slides pre-coated with $0.5 \%$ normal melting point (NMP) agarose and immediately covered with a cover slip and kept for 10 minutes in a refrigerator to solidify. After gently removing the 
coverslips, the slides were coated with a third layer of 75 $\mu \mathrm{l}$ low-melting point agarose and covered with glass slip again. After solidification of gel, the slides were immersed in the cold lysing solution and refrigerated at $4{ }^{\circ} \mathrm{C}$, followed by electrophoresis $(25 \mathrm{~V}, 300 \mathrm{~mA}$ for 25 minutes) and staining with ethidium bromide. Two slides were prepared and one hundred and fifty cells per slide were scored randomly and analyzed by using an image analysis system attached to Epi-Fluorescence microscope (N-400M, American Scope; UK) equipped with light source of mercury short arc reflector lamp filters for ethidium bromide at $400 \mathrm{X}$ magnification and low lux (MD-800, American Scope; UK) camera.

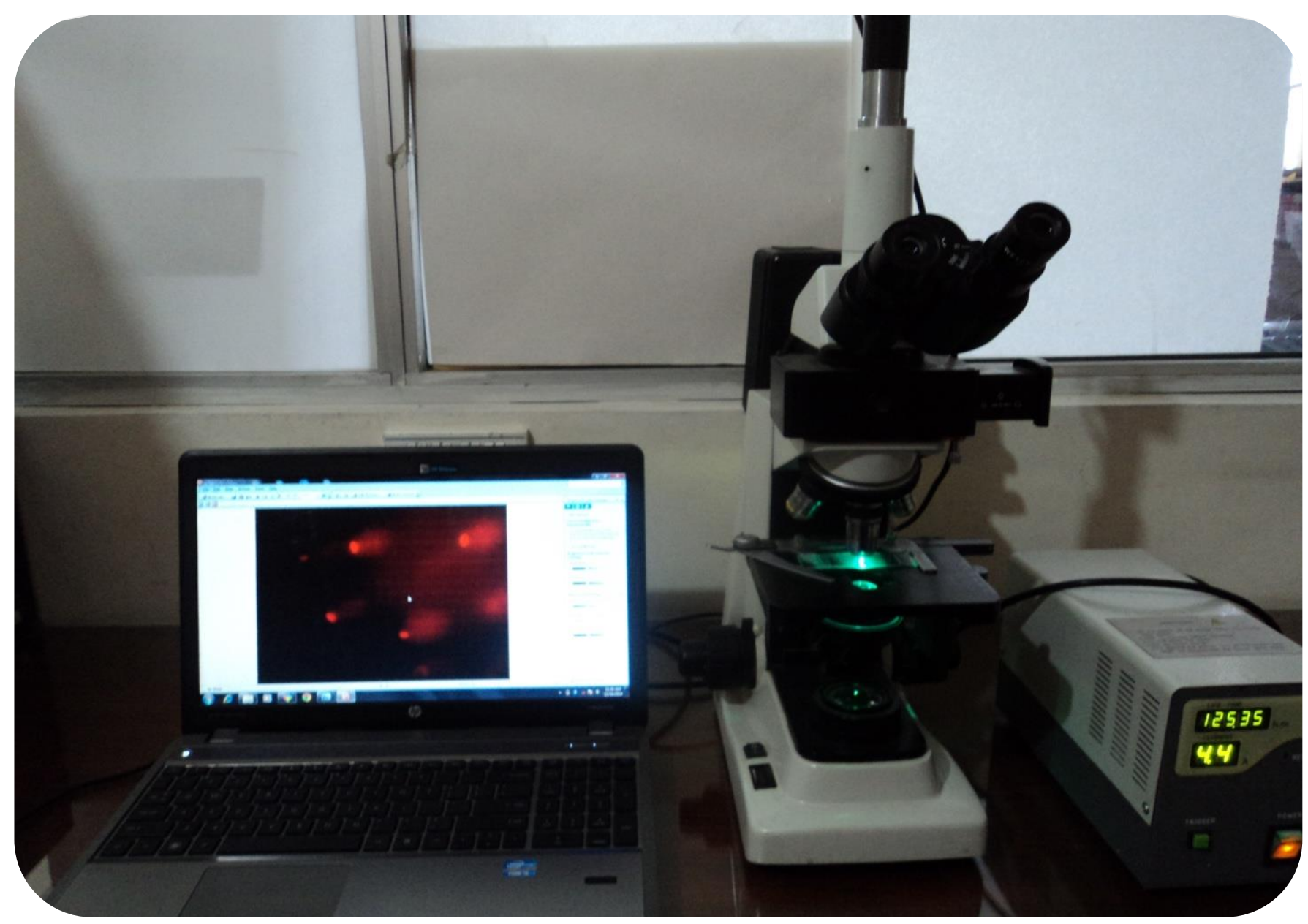

Figure 1. Caption is missing

The DNA damage was quantified by visual classification of cells into four classes of "comets" (Figure 1) corresponding to the tail length (measured through TriTek CometScore ${ }^{\mathrm{TM}}$ ) as undamaged (Class 0 ); low level damage (Class I); medium level damage (Class II); high level damage: (Class III) and complete damage (Class IV). All steps were conducted in dim light to avoid any nonspecific additional breakage of DNA. The extent of DNA damage was examined as the mean percentage of cells with medium, high and complete damaged DNA, which was calculated as the sum of cells with class II+III+IV. Statistical analyses were performed by using MSTATC computer software. Results were expressed as Means \pm SD. A p-value of less than 0.05 were considered statistically significant. Means of data were compared for the statistical differences by using Duncan Range Multiple tests (Steel et al., 1996). 


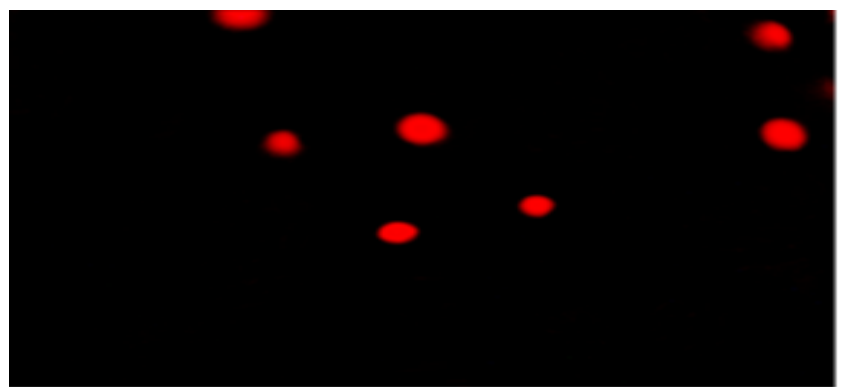

Control

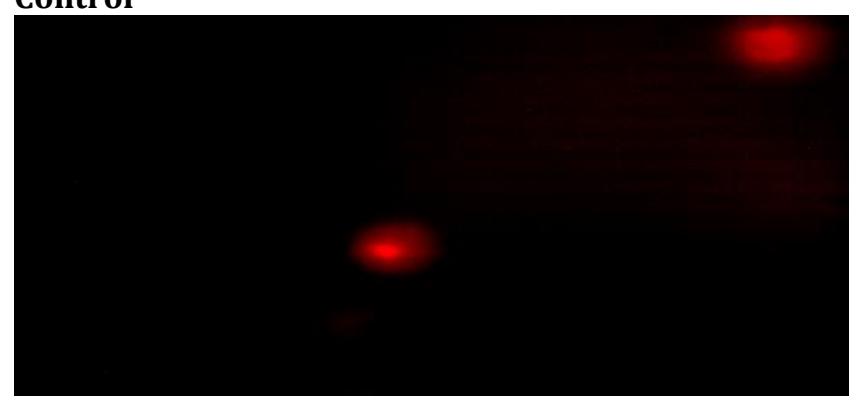

Class-I

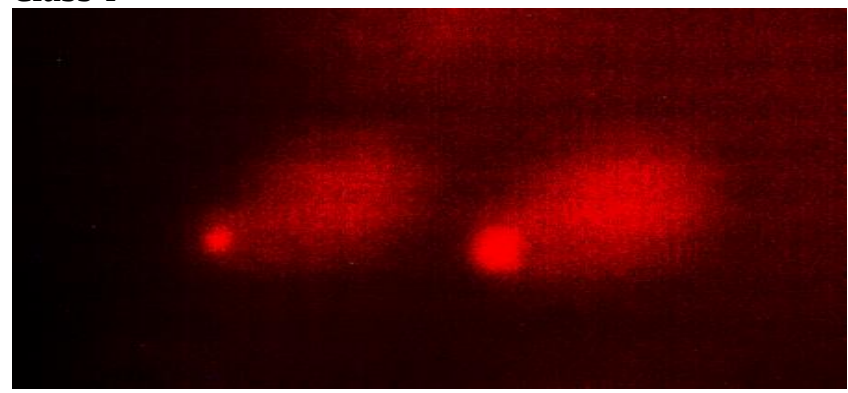

Class-III

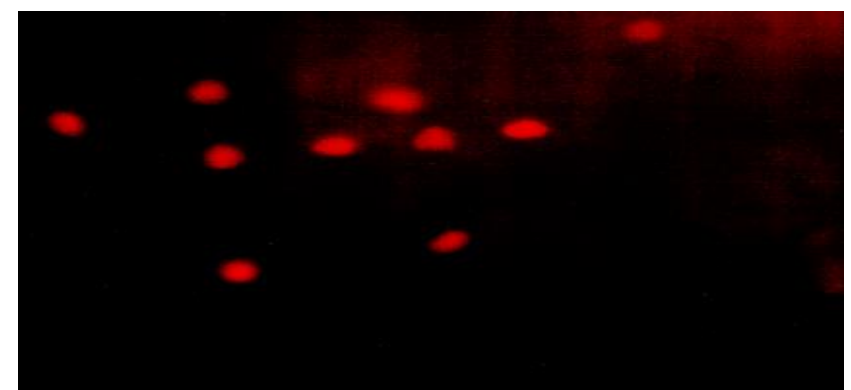

Class-0

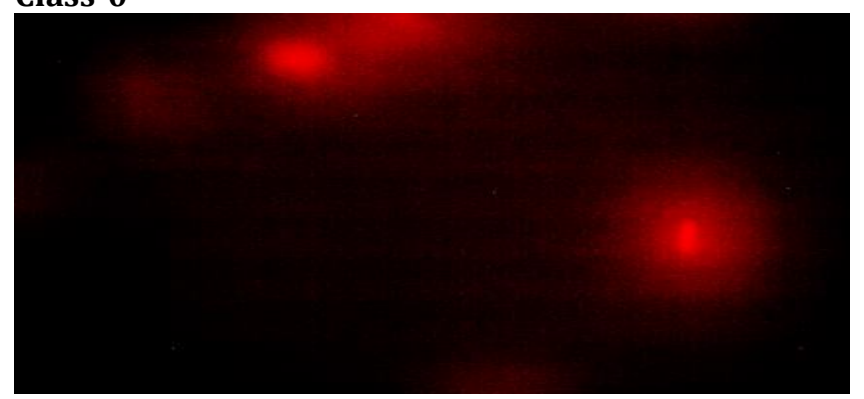

Class-II

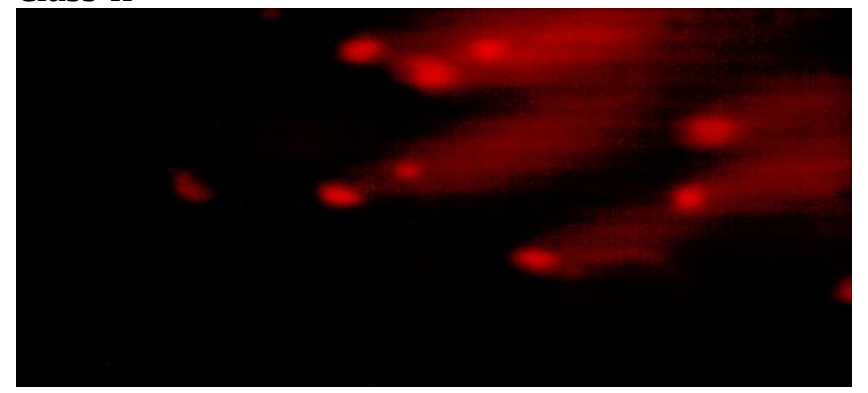

Class-IV

Figure 1. Comet class categories used for the estimation of the percentage of damaged cells.

\section{RESULTS}

DNA damaging effect of bifenthrin and chlorpyrifos mixture was investigated by using the comet assay. Table 1 shows the significantly variable proportion of undamaged (normal cells) and damaged class nuclei in the peripheral erythrocytes of Cyprinus carpio underexposure of negative control, positive control and $33 \% \mathrm{LC}_{50}$ during five fortnights. It was observed that the proportion of damaged cells changed with the duration of exposure to pesticide mixture (bifenthrin + chlorpyrifos). Results showed that fish exposed to $33 \% \mathrm{LC}_{50}$ exhibited significantly higher DNA damage in their peripheral blood erythrocytes as compared to control groups. Among all treatments, viz. negative control, positive control and 33\% LC 50 , the proportion of class-0 (normal cells) were observed significantly higher in the negative control group during all fortnights while the proportion of normal cells were minimum under the exposure of $33 \% \mathrm{LC}_{50}$. However, the proportion of comet class-I damaged cells were maximum during the $1^{\text {st }}, 2^{\text {nd }}$ and a $5^{\text {th }}$ fortnight at $33 \% \mathrm{LC}_{50}$ exposure while during $3^{\text {rd }}$ and $4^{\text {th }}$ fortnight same were observed higher due to the positive control treatment. Proportions of comet class-II damaged nuclei were also varied significantly during the various fortnights of this study period. During the first two fortnights, proportions of comet class-II cells were observed higher due to the positive control treatment. However, during $3^{\text {rd }}, 4^{\text {th }}$ and $5^{\text {th }}$ fortnights, $33 \% \mathrm{LC}_{50}$ gave a significantly higher proportion of class-II cells. Among various treatments, viz. negative control, positive control and $33 \% \mathrm{LC}_{50}$, the frequency of cells with high-level damage (class-III) and complete damage (class-IV) were observed significantly higher due to $33 \% \quad \mathrm{LC}_{50}$ exposure of pesticides mixture. The proportion of class-III damaged cells were ranged from $24.67 \pm 1.15-33.33 \pm 1.15$, exhibited a concomitant increase in damage from $1^{\text {st }}$ to a $3^{\text {rd }}$ fortnight. The proportion of all comet classes exhibited time-dependent increase or decrease in DNA damage from $1^{\text {st }}$ to a $5^{\text {th }}$ fortnight. 
Table 1 DNA damage in peripheral blood erythrocytes of Cyprinus carpio exposed to a binary mixture of bifenthrin and chlorpyrifos.

\begin{tabular}{|c|c|c|c|c|c|c|c|c|c|}
\hline \multirow{2}{*}{ Fortnights } & \multirow{2}{*}{ Treatments } & \multirow{2}{*}{$\begin{array}{c}\text { Undamaged } \\
\text { Nuclei (\%) } \\
\text { Class-0 }\end{array}$} & \multicolumn{4}{|c|}{ Comet Classes (Damaged Nuclei (\%)) } & \multirow{2}{*}{$\begin{array}{l}\text { *Percentage of } \\
\text { Damaged Cells }\end{array}$} & \multirow{2}{*}{${ }^{* *} \mathrm{GDI}$} & \multirow{2}{*}{${ }^{* * *} \operatorname{CTL}(\mu \mathrm{m})$} \\
\hline & & & Class-I & Class-II & Class-III & Class-IV & & & \\
\hline \multirow[t]{3}{*}{$1^{\text {st }}$} & $\begin{array}{l}\text { Negative } \\
\text { Control }\end{array}$ & $98.00 \pm 0.00 \mathrm{a}$ & $2.00 \pm 0.00 \mathrm{c}$ & $0.00 \pm 0.00 \mathrm{c}$ & $0.00 \pm 0.00 \mathrm{c}$ & $0.00 \pm 0.00 \mathrm{c}$ & $0.00 \pm 0.00 \mathrm{c}$ & $0.02 \pm 0.00 \mathrm{c}$ & $3.23 \pm 0.03 \mathrm{c}$ \\
\hline & $\begin{array}{l}\text { Positive } \\
\text { Control }\end{array}$ & $34.00 \pm 0.00 \mathrm{~b}$ & $14.67 \pm 1.15 \mathrm{~b}$ & $18.00 \pm 2.00 \mathrm{a}$ & $10.67 \pm 1.15 b$ & $22.67 \pm 1.15 \mathrm{a}$ & $51.33 \pm 1.15 \mathrm{~b}$ & $1.73 \pm 0.01 \mathrm{~b}$ & $128.15 \pm 0.05 b$ \\
\hline & $33 \%$ of $\mathrm{LC}_{50}$ & $21.33 \pm 1.15 \mathrm{c}$ & $25.33 \pm 1.15 \mathrm{a}$ & $10.67 \pm 1.15 \mathrm{~b}$ & $24.67 \pm 1.15 \mathrm{a}$ & $18.00 \pm 2.00 \mathrm{~b}$ & $53.33 \pm 2.31 \mathrm{ab}$ & $1.93 \pm 0.08 \mathrm{a}$ & $572.37 \pm 0.06 \mathrm{a}$ \\
\hline \multirow[t]{3}{*}{$2^{\text {nd }}$} & $\begin{array}{l}\text { Negative } \\
\text { Control }\end{array}$ & $98.00 \pm 0.00 \mathrm{a}$ & $2.00 \pm 0.00 \mathrm{c}$ & $0.00 \pm 0.00 \mathrm{c}$ & $0.00 \pm 0.00 \mathrm{c}$ & $0.00 \pm 0.00 \mathrm{~b}$ & $0.00 \pm 0.00 \mathrm{c}$ & $0.02 \pm 0.00 \mathrm{c}$ & $3.19 \pm 0.08 \mathrm{c}$ \\
\hline & $\begin{array}{l}\text { Positive } \\
\text { Control }\end{array}$ & $32.00 \pm 2.00 \mathrm{~b}$ & $14.00 \pm 2.00 \mathrm{~b}$ & $19.33 \pm 1.15 \mathrm{ab}$ & $14.67 \pm 1.15 \mathrm{~b}$ & $20.00 \pm 2.00 \mathrm{a}$ & $54.00 \pm 0.00 \mathrm{~b}$ & $1.77 \pm 0.04 \mathrm{~b}$ & $130.56 \pm 0.05 \mathrm{~b}$ \\
\hline & $33 \%$ of $\mathrm{LC}_{50}$ & $14.67 \pm 1.15 \mathrm{c}$ & $21.33 \pm 1.15 \mathrm{a}$ & $17.33 \pm 3.06 \mathrm{bc}$ & $26.67 \pm 1.15 \mathrm{a}$ & $20.00 \pm 2.00 \mathrm{a}$ & $64.00 \pm 0.00 \mathrm{a}$ & $2.16 \pm 0.04 \mathrm{a}$ & $678.20 \pm 0.05 \mathrm{a}$ \\
\hline \multirow[t]{3}{*}{$3^{\text {rd }}$} & $\begin{array}{l}\text { Negative } \\
\text { Control }\end{array}$ & $98.00 \pm 0.00 \mathrm{a}$ & $2.00 \pm 0.00 \mathrm{c}$ & $0.00 \pm 0.00 \mathrm{c}$ & $0.00 \pm 0.00 \mathrm{c}$ & $0.00 \pm 0.00 \mathrm{c}$ & $0.00 \pm 0.00 \mathrm{c}$ & $0.02 \pm 0.00 \mathrm{c}$ & $3.22 \pm 0.04 \mathrm{c}$ \\
\hline & $\begin{array}{l}\text { Positive } \\
\text { Control }\end{array}$ & $38.00 \pm 2.00 \mathrm{~b}$ & $15.33 \pm 1.15 \mathrm{ab}$ & $14.67 \pm 1.15 \mathrm{~b}$ & $10.67 \pm 1.15 \mathrm{~b}$ & $21.33 \pm 1.15 b$ & $46.67 \pm 2.31 \mathrm{~b}$ & $1.62 \pm 0.07 \mathrm{~b}$ & $128.70 \pm 0.10 \mathrm{~b}$ \\
\hline & $33 \%$ of $\mathrm{LC}_{50}$ & $10.67 \pm 1.15 \mathrm{c}$ & $12.00 \pm 2.00 \mathrm{~b}$ & $20.00 \pm 2.00 \mathrm{a}$ & $33.33 \pm 1.15 \mathrm{a}$ & $24.00 \pm 2.00 \mathrm{a}$ & $77.33 \pm 1.15 \mathrm{a}$ & $2.48 \pm 0.04 \mathrm{a}$ & $694.51 \pm 0.14 \mathrm{a}$ \\
\hline \multirow[t]{3}{*}{$4^{\text {th }}$} & $\begin{array}{l}\text { Negative } \\
\text { Control }\end{array}$ & $98.00 \pm 0.00 \mathrm{a}$ & $2.00 \pm 0.00 \mathrm{c}$ & $0.00 \pm 0.00 \mathrm{c}$ & $0.00 \pm 0.00 \mathrm{c}$ & $0.00 \pm 0.00 \mathrm{c}$ & $0.00 \pm 0.00 \mathrm{c}$ & $0.02 \pm 0.00 \mathrm{c}$ & $3.42 \pm 0.08 \mathrm{c}$ \\
\hline & $\begin{array}{l}\text { Positive } \\
\text { Control }\end{array}$ & $30.67 \pm 1.15 b$ & $12.67 \pm 2.31 \mathrm{ab}$ & $20.00 \pm 2.00 \mathrm{~b}$ & $16.67 \pm 1.15 \mathrm{~b}$ & $20.00 \pm 2.00 \mathrm{ab}$ & $56.67 \pm 1.15 \mathrm{~b}$ & $1.83 \pm 0.04 \mathrm{~b}$ & $134.58 \pm 0.07 \mathrm{~b}$ \\
\hline & $33 \%$ of $\mathrm{LC}_{50}$ & $9.33 \pm 2.31 \mathrm{c}$ & $11.33 \pm 1.15 \mathrm{~b}$ & $34.00 \pm 3.46 \mathrm{a}$ & $27.33 \pm 1.15 \mathrm{a}$ & $18.00 \pm 2.00 \mathrm{bc}$ & $79.33 \pm 1.15 \mathrm{a}$ & $2.33 \pm 0.01 \mathrm{a}$ & $681.35 \pm 0.05 \mathrm{a}$ \\
\hline \multirow[t]{3}{*}{$5^{\text {th }}$} & $\begin{array}{l}\text { Negative } \\
\text { Control }\end{array}$ & $97.33 \pm 1.15 \mathrm{a}$ & $2.67 \pm 1.15 \mathrm{c}$ & $0.00 \pm 0.00 \mathrm{c}$ & $0.00 \pm 0.00 \mathrm{c}$ & $0.00 \pm 0.00 \mathrm{~b}$ & $0.00 \pm 0.00 \mathrm{c}$ & $0.03 \pm 0.01 \mathrm{c}$ & $3.45 \pm 0.05 \mathrm{c}$ \\
\hline & $\begin{array}{l}\text { Positive } \\
\text { Control }\end{array}$ & $30.00 \pm 2.00 \mathrm{~b}$ & $14.67 \pm 1.15 \mathrm{~b}$ & $16.67 \pm 1.15 \mathrm{~b}$ & $18.00 \pm 2.00 \mathrm{~b}$ & $20.67 \pm 1.15 \mathrm{a}$ & $55.33 \pm 1.15 \mathrm{~b}$ & $1.85 \pm 0.06 \mathrm{~b}$ & $139.54 \pm 0.04 \mathrm{~b}$ \\
\hline & $33 \%$ of $\mathrm{LC}_{50}$ & $8.67 \pm 1.15 \mathrm{c}$ & $18.00 \pm 2.00 \mathrm{ab}$ & $21.33 \pm 1.15 \mathrm{a}$ & $31.33 \pm 3.06 \mathrm{a}$ & $20.67 \pm 1.15 \mathrm{a}$ & $73.33 \pm 3.06 \mathrm{a}$ & $2.37 \pm 0.09 \mathrm{a}$ & $713.70 \pm 0.06 \mathrm{a}$ \\
\hline
\end{tabular}

The means with similar letters in a single column for each variable are statistically non-significant at $\mathrm{p}<0.05$.

*Percentage of Damaged Cells = Class-II + Class-III + Class-IV;

${ }^{* *}$ GDI (Genetic Damage Index $)=\{($ Class-I) +2 (Class-II) +3 (Class-III) +4 (Class-IV) $/$ Class- $0+$ Class-I + Class-II + Class-III + Class-IV $\}$;

${ }^{* * *} \mathrm{CTL}=$ Cumulative Tail Length of Comets. 
Table 2. Time and dose-related DNA damage in Cyprinus crpio.

\begin{tabular}{|c|c|c|c|c|}
\hline & & $\begin{array}{l}\text { Percentage of } \\
\text { Damaged Cells }\end{array}$ & $\begin{array}{c}{ }^{*} \text { GDI } \\
\text { (Genetic Damage } \\
\text { Index) }\end{array}$ & $\begin{array}{c}{ }^{* *} \text { CTL }(\mu \mathrm{m}) \\
\text { (Cumulative Tail } \\
\text { Length) }\end{array}$ \\
\hline \multicolumn{5}{|c|}{ Dose-Dependent Genotoxicity } \\
\hline \multirow{3}{*}{ Treatments } & Negative Control & $0.00 \pm 0.00 \mathrm{c}$ & $0.02 \pm 0.00 \mathrm{c}$ & $3.30 \pm 0.12 \mathrm{c}$ \\
\hline & Positive Control & $52.80 \pm 3.95 \mathrm{~b}$ & $1.76 \pm 0.09 \mathrm{~b}$ & $132.31 \pm 4.77 \mathrm{~b}$ \\
\hline & $33 \%$ of $\mathrm{LC}_{50}$ & $69.46 \pm 10.77 \mathrm{a}$ & $2.25 \pm 0.21 \mathrm{a}$ & $668.03 \pm 55.27 \mathrm{a}$ \\
\hline
\end{tabular}

Time-Dependent Genotoxicity

Fortnights $\left\{\begin{array}{cccc}1 \text { st } & 34.89 \pm 30.23 \mathrm{e} & 1.23 \pm 1.05 \mathrm{e} & 234.58 \pm 299.13 \mathrm{e} \\ 2^{\text {nd }} & 39.33 \pm 34.43 \mathrm{~d} & 1.32 \pm 1.14 \mathrm{~d} & 270.65 \pm 358.65 \mathrm{~d} \\ 3^{\text {rd }} & 41.33 \pm 38.94 \mathrm{bc} & 1.37 \pm 1.25 \mathrm{c} & 275.48 \pm 368.28 \mathrm{~b} \\ 4^{\text {th }} & 45.33 \pm 40.86 \mathrm{a} & 1.39 \pm 1.22 \mathrm{~b} & 273.12 \pm 359.57 \mathrm{c} \\ 5^{\text {th }} & 42.89 \pm 38.22 \mathrm{~b} & 1.42 \pm 1.23 \mathrm{a} & 285.56 \pm 376.97 \mathrm{a}\end{array}\right.$

The means with similar letters in a single column for each variable are statistically non-significant at $\mathrm{p}<0.05$.

Table 2 shows dose and time-based variations in the percentage of damaged cells, genetic damage index and a cumulative tail length of comets $(\mu \mathrm{m})$ in the peripheral blood erythrocytes of Cyprinus carpio. In the present study, DNA damage showed time and dose-dependent relationship. All comet parameters viz. percentage of damaged cells, genetic damage index and a cumulative tail length of comets $(\mu \mathrm{m})$ were observed higher at 33\% $\mathrm{LC}_{50}$, followed by that of positive and negative control exhibiting dose-dependent DNA damage with statistically significant differences among them. Damaged cells (\%) increased gradually and reached at maximum during $4^{\text {th }}$ fortnight $(45.33 \pm 40.86 \%)$ while during $5^{\text {th }}$ fortnight (42.89 $\pm 38.22 \%)$ slight decrease was observed exhibiting that DNA damage increased significantly with duration of exposure. However, genetic damage indices were maximum (1.42 \pm 1.23$)$ and minimum $(1.23 \pm 1.05)$ during $5^{\text {th }}$ and $1^{\text {st }}$ fortnight, respectively. The cumulative tail length of comets $(\mu \mathrm{m})$ gradually increased from $1^{\text {st }}$ to a $3^{\text {rd }}$ fortnight $(234.58 \pm 299.13$ to $275.48 \pm 368.28 \mu \mathrm{m})$ however, at $4^{\text {th }}$-fortnight slight decrease in length of comets were observed as evident from their mean value of $273.12 \pm 359.57 \mu \mathrm{m}$ but during $5^{\text {th }}$ fortnight it again increased linearly up to $285.56 \pm 376.97 \mu \mathrm{m}$.

\section{DISCUSSION}

Pesticide effects on organisms were often investigated by using single toxicants under laboratory conditions. However, under environmental conditions a mixture of pesticides or pesticide metabolites were present which may cause interactive effects. Pesticides may cause DNA damage directly due to the action of a parental compound or their metabolites and indirectly by the generation of reactive oxygen species (Oliveira et al., 2009). During present study time and dose-dependent DNA damage was observed underexposure of bifenthrin + chlorpyrifos mixture. Similarly, a significant increase in DNA damage was observed by Polard et al. (2011) under the exposure of pesticide mixture, chlorotouron + atrazine + isoproturon + metachlor + deethylatrazine as compared to the control group. Dose and time-dependent genotoxicity in fish associated with pesticide exposure using the single cell gel electrophoresis assay in fish erythrocytes is well documented (Nwani et al., 2010 and 2013; Pandey et al., 2011; Yong et al., 2011; Rani and Kumaraguru, 2013). Pesticide mixture, chlorpyrifos + endosulfan + thiraam has also been reported to cause 
significant DNA damage (Tope and Rogers, 2009). Arcaute et al. (2014) observed that even acute exposure of herbicide (dicamba) can increase the frequency of primary DNA lesions in circulating blood cells of tropical fish estimated by alkaline single cell gel electrophoresis.

All previously discussed genotoxicity assessment was based on evaluation of acute exposure effects. Such an approach fails to provide relevant information regarding the long-term effects of pesticide burden on the genome. Therefore, the main idea of the present study was to characterize DNA damage induced by prolonged exposure to bifenthrin + chlorpyrifos. The binding of chlorpyrifos with DNA to produce DNA adducts leads to an increasing concern about the genotoxic risk of chlorpyrifos in fish. Li et al. (2015) observed that the sublethal concentrations of chlorpyrifos induced significant concentration-dependent single strand DNA breaks in the treated cells as compared to control group and conclude that chlorpyrifos is a strongly genotoxic agent that can induce DNA damage and cell apoptosis. DNA strand breaks have been mainly ascribed to the excessive accumulation of reactive oxygen species therefore, it was possible that DNA adducts, and reactive oxygen species contribute to the bifenthrin + chlorpyrifos mediated DNA damage. The decrease in the percentage of DNA damage after $4^{\text {th }}$ fortnight day of exposure as observed in the fish exposed to pesticide mixture might indicate the repair of damaged DNA, loss of heavily damaged cells or both. The tail length determines how far the DNA has migrated out of the cell. Smaller DNA fragments move the farthest; therefore, the tail length is predominantly dictated by the size of the DNA fragments generated during the alkaline unwinding step of the single cell gel electrophoresis (Kumaravel and Jha, 2006).

\section{CONCLUSION}

Knowledge of the sub-lethal effects of pesticides on the genetic level is very crucial for delineating fish health status and for understanding the future ecological impacts. The current study of DNA damage caused by pesticide mixture may become a key indicator in assessing the general health of freshwater fish. This would also identify the importance of genotoxicity as a monitoring factor for predicting the impacts of pollution on the fish.

\section{ACKNOWLEDGEMENTS}

The author is grateful to the "HIGHER EDUCATION COMMISSION, PAKISTAN" for providing funds under Indigenous $\mathrm{PhD}$ fellowship program to complete this work as a part of $\mathrm{PhD}$ research.

\section{REFERENCES}

Ambreen, F., Javed, M., 2015. Assessment of acute toxicity of pesticides mixtures for Cyprinus carpio and Ctenopharyngodon idella. Pakistan Journal of Zoology 47.

Araldi, R.P., de Melo, T.C., Mendes, T.B., de Sá Júnior, P.L., Nozima, B.H.N., Ito, E.T., de Carvalho, R.F., de Souza, E.B., de Cassia Stocco, R., 2015. Using the comet and micronucleus assays for genotoxicity studies: A review. Biomedicine \& Pharmacotherapy 72, 7482.

Azqueta, A., Collins, A.R., 2013. The essential comet assay: a comprehensive guide to measuring DNA damage and repair. Archives of Toxicology 87, 949-968.

Cui, Y., Guo, J., Xu, B., Chen, Z., 2010. Genotoxicity of chlorpyrifos and cypermethrin to ICR mouse hepatocytes. Toxicology Mechanisms and Methods 21, 70-74.

de Arcaute, C.R., Soloneski, S., Larramendy, M.L., 2014. Evaluation of the genotoxicity of a herbicide formulation containing 3, 6-dichloro-2metoxybenzoic acid (dicamba) in circulating blood cells of the tropical fish Cnesterodon decemmaculatus. Mutation Research/Genetic Toxicology and Environmental Mutagenesis 773, 18.

Grube, A., Donaldson, D., Kiel, T., Wu, L., 2011. Pesticides industry sales and usage, 2006 and 2007 Market Estimates, Agency, E P ed.

Guanggang, X., Diqiu, L., Jianzhong, Y., Jingmin, G., Huifeng, Z., Mingan, S., Liming, T., 2013. Carbamate insecticide methomyl confers cytotoxicity through DNA damage induction. Food and Chemical Toxicology 53, 352-358.

Hartmann, A., 2004. Use of the alkaline in vivo Comet assay for mechanistic genotoxicity investigations. Mutagenesis 19, 51-59.

Jin, Y., Liu, Z., Peng, T., Fu, Z., 2015. The toxicity of chlorpyrifos on the early life stage of zebrafish: A survey on the endpoints at development, locomotor behavior, oxidative stress and immunotoxicity. Fish \& Shellfish Immunology 43, 405-414.

Jin, Y., Liu, Z., Peng, T., Fu, Z., 2015. The toxicity of chlorpyrifos on the early life stage of zebrafish: A survey on the endpoints at development, locomotor behavior, oxidative stress and 
immunotoxicity. Fish \& Shellfish Immunology 43, 405-414.

Kumaravel, T.S., Jha, A.N., 2006. Reliable Comet assay measurements for detecting DNA damage induced by ionising radiation and chemicals. Mutation Research/Genetic Toxicology and Environmental Mutagenesis 605, 7-16.

Li, D., Huang, Q., Lu, M., Zhang, L., Yang, Z., Zong, M., Tao, L., 2015. The organophosphate insecticide chlorpyrifos confers its genotoxic effects by inducing DNA damage and cell apoptosis. Chemosphere 135, 387-393.

Malaj, E., von der Ohe, P.C., Grote, M., Kühne, R., Mondy, C.P., Usseglio-Polatera, P., Brack, W., Schäfer, R.B., 2014. Organic chemicals jeopardize the health of freshwater ecosystems on the continental scale. Proceedings of the National Academy of Sciences 111, 9549-9554.

Malling, H.V., 2004. History of the science of mutagenesis from a personal perspective. Environmental and Molecular Mutagenesis 44, 372-386.

Nwani, C.D., Lakra, W.S., Nagpure, N.S., Kumar, R., Kushwaha, B., Srivastava, S.K., 2010. Mutagenic and genotoxic effects of carbosulfan in freshwater fish Channa punctatus (Bloch) using micronucleus assay and alkaline single-cell gel electrophoresis. Food and Chemical Toxicology 48, 202-208.

Nwani, C.D., Nagpure, N.S., Kumar, R., Kushwaha, B., Lakra, W.S., 2013. DNA damage and oxidative stress modulatory effects of glyphosate-based herbicide in freshwater fish, Channa punctatus. Environmental Toxicology and Pharmacology 36, 539-547.

Oliveira, M., Maria, V.L., Ahmad, I., Serafim, A., Bebianno, M.J., Pacheco, M., Santos, M.A., 2009. Contamination assessment of a coastal lagoon (Ria de Aveiro, Portugal) using defence and damage biochemical indicators in gill of Liza aurata - An integrated biomarker approach. Environmental Pollution 157, 959-967.

Ostling, O., Johanson, K.J., 1984. Microelectrophoretic study of radiation-induced DNA damages in individual mammalian cells. Biochemical and Biophysical Research Communications 123, 291298.

Pandey, A.K., Nagpure, N.S., Trivedi, S.P., Kumar, R., Kushwaha, B., 2011. Profenofos induced DNA damage in freshwater fish, Channa punctatus
(Bloch) using alkaline single cell gel electrophoresis. Mutation Research/Genetic Toxicology and Environmental Mutagenesis 726, 209-214.

Pfeiffer, P., Goedecke, W., Obe, G., 2000. Mechanisms of DNA double-strand break repair and their potential to induce chromosomal aberrations. Mutagenesis 15, 289-302.

Polard, T., Jean, S., Gauthier, L., Laplanche, C., Merlina, G., Sánchez-Pérez, J.M., Pinelli, E., 2011. Mutagenic impact on fish of runoff events in agricultural areas in south-west France. Aquatic Toxicology 101, 126134.

Ponepal, C.M., Păunescu, A., Drăghici, O., Marinescu, A.G., 2006. Research on the changes of some physiological parameters in several fish species under the action of the thiametoxame insecticide, Proceedings 36th International Conference of IAD, pp. 163-167.

Rani, A.P.A., Kumaraguru, A.K., 2013. DNA integrity as molecular biomarker of genotoxic effect of endosulfan in Oreochromis mossambicus (Peters). International Journal of Engineering Science Invention 2, 58-61.

Rasmussen, J.J., Wiberg-Larsen, P., Baattrup-Pedersen, A., Cedergreen, N., McKnight, U.S., Kreuger, J., Jacobsen, D., Kristensen, E.A., Friberg, N., 2015. The legacy of pesticide pollution: An overlooked factor in current risk assessments of freshwater systems. Water Research 84, 25-32.

Roy, D., Petrobich, Z.A., Aleksebich, B.B., Latifa, G.A., 2018. Intensive polyculture of common carp (Cyprinus carpio), mirror carp (Cyprinus carpio carpio), silver carp (Hypophthalmichthys Molitrix) and grass carp (Ctenopharyngodon Idella) at different stocking densities. Bangladesh Journal of Zoology 46, 71-80.

Ruiz de Arcaute, C., Soloneski, S., Larramendy, M.L., 2014. Evaluation of the genotoxicity of a herbicide formulation containing 3,6-dichloro-2metoxybenzoic acid (dicamba) in circulating blood cells of the tropical fish Cnesterodon decemmaculatus. Mutation Research/Genetic Toxicology and Environmental Mutagenesis 773, 18.

Ruiz-Suárez, N., Boada, L.D., Henríquez-Hernández, L.A., González-Moreo, F., Suárez-Pérez, A., Camacho, M., Zumbado, M., Almeida-González, M., del Mar 
Travieso-Aja, M., Luzardo, O.P., 2015. Continued implication of the banned pesticides carbofuran and aldicarb in the poisoning of domestic and wild animals of the Canary Islands (Spain). Science of The Total Environment 505, 1093-1099.

Singh, N.P., McCoy, M.T., Tice, R.R., Schneider, E.L., 1988. A simple technique for quantitation of low levels of DNA damage in individual cells. Experimental Cell Research 175, 184-191.

Steel, R.G.D., Torrie, J.H., Dinkkey, D.A., 1996. Principles and procedures of statistics McGraw Hill Book Co,
Singapore.

Topè, A.M., Rogers, P.F., 2009. Evaluation of protective effects of sulforaphane on DNA damage caused by exposure to low levels of pesticide mixture using comet assay. Journal of Environmental Science and Health, Part B 44, 657-662.

Yen, J., Donerly, S., Levin, E.D., Linney, E.A., 2011. Differential acetylcholinesterase inhibition of chlorpyrifos, diazinon and parathion in larval zebrafish. Neurotoxicology and Teratology 33, 735-741.

Publisher's note: EScience Press remains neutral with regard to jurisdictional claims in published maps and institutional affiliations.

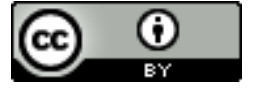

Open Access This article is licensed under a Creative Commons Attribution 4.0 International License, which permits use, sharing, adaptation, distribution and reproduction in any medium or format, as long as you give appropriate credit to the original author(s) and the source, provide a link to the Creative Commons license and indicate if changes were made. The images or other third-party material in this article are included in the article's Creative Commons license, unless indicated otherwise in a credit line to the material. If material is not included in the article's Creative Commons license and your intended use is not permitted by statutory regulation or exceeds the permitted use, you will need to obtain permission directly from the copyright holder. To view a copy of this license, visit http://creativecommons.org/licenses/by/4.0/.

(C) The Author(s) 2019 . 